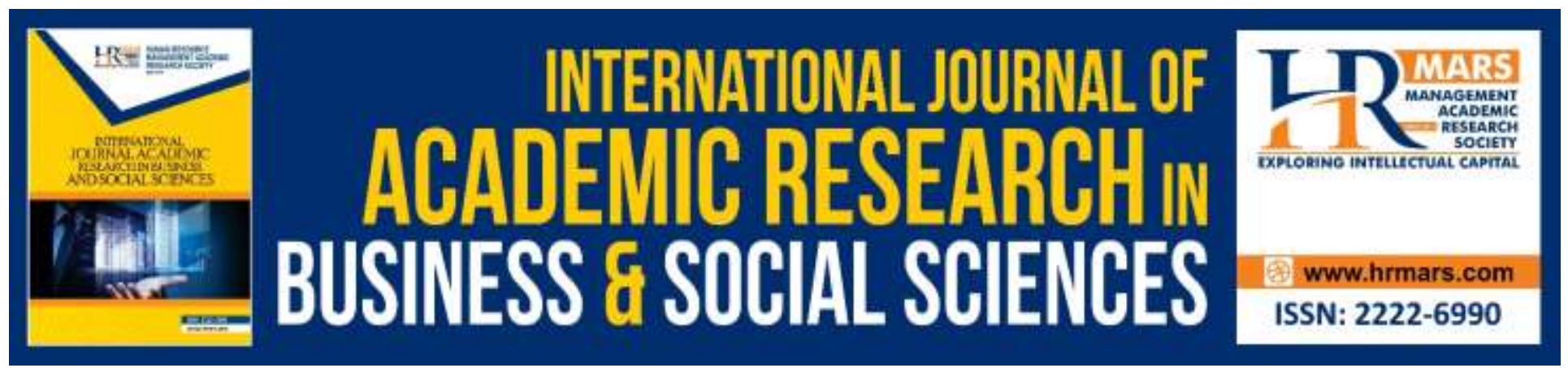

\title{
The Parenting Environment in the Contemporary Agĩkũyũ Community of Kenya
}

\author{
P. N. Wachege, Florida G. Rũgendo
}

To Link this Article: http://dx.doi.org/10.6007/IJARBSS/v8-i8/4446

DOI: $10.6007 /$ IJARBSS/v8-i8/4446

Received: 09 July 2018, Revised: 27 July 2018, Accepted: 16 August 2018

Published Online: 30 August 2018

In-Text Citation: (Wachege \& Rũgendo, 2018)

To Cite this Article: Wachege, P. N., \& Rũgendo, F. G. (2018). The Parenting Environment in the Contemporary Agĩkũyũ Community of Kenya. International Journal of Academic Research in Business and Social Sciences, 8(8), 135-148.

\section{Copyright: (c) 2018 The Author(s)}

Published by Human Resource Management Academic Research Society (www.hrmars.com)

This article is published under the Creative Commons Attribution (CC BY 4.0) license. Anyone may reproduce, distribute, translate and create derivative works of this article (for both commercial and non-commercial purposes), subject to full attribution to the original publication and authors. The full terms of this license may be seen

at: http://creativecommons.org/licences/by/4.0/legalcode

Vol. 8, No. 8, August 2018, Pg. 135 - 148

Full Terms \& Conditions of access and use can be found at http://hrmars.com/index.php/pages/detail/publication-ethics 


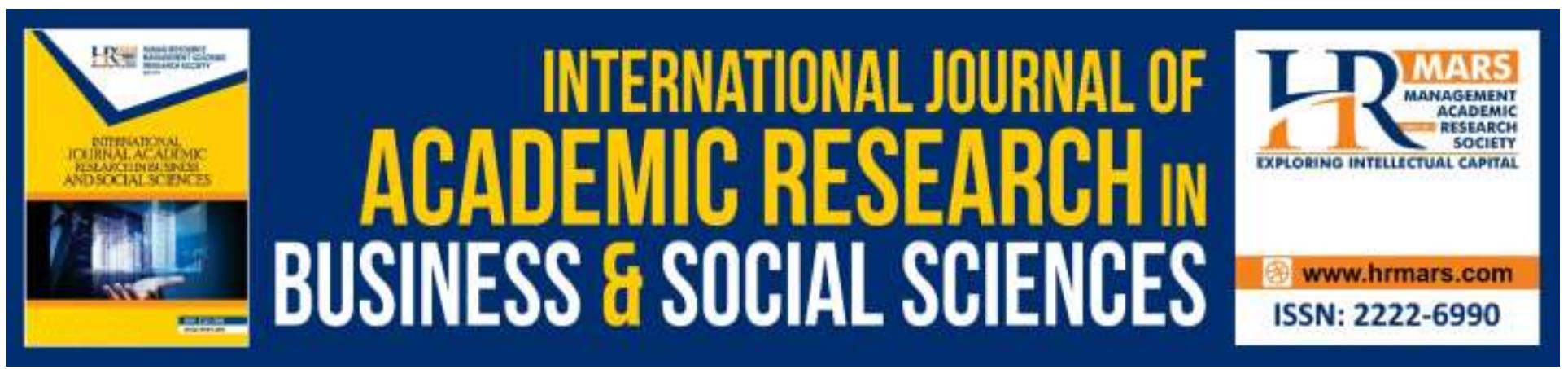

\title{
The Parenting Environment in the Contemporary Agĩkũyũ Community of Kenya
}

\author{
Prof. P. N. Wachege \\ Department of Philosophy and Religious Studies, University of Nairobi \\ Email: patricknwachege@gmail.com \\ Florida G. Rũgendo \\ PhD Candidate, Department of Philosophy and Religious Studies, University of Nairobi \\ Email: fkamakia@gmail.com
}

\begin{abstract}
Children need to grow in an open and friendly environment where they know what to expect and what is expected of them for a positive parenting outcome. The right environment provides a sense of security and comfort to the child. Research is rife with evidence that the environment in which children are brought up today has transformed as society and family continue to adjust to social and economic changes, but none has delved deeper into that of the contemporary Agĩkũyũ community living in Karũrĩ Catholic Parish. Our study therefore examines the parenting environment within the Agĩkũyũ community responsible in bringing up morally upright individuals. This is done with the aim of proffering strategic choices for recovery of some of its application towards holistic parenting today. The descriptive survey research design is engaged and data collected through questionnaires, interviews and observation techniques. The study finds the environment in which children were brought up in the older Agĩkũyũ society to have changed significantly resulting in deprived parenting. Today personal goals prevail over those of the community. Family and community relationships have also changed and a new culture is taking place among the youth. It is recommended that parents reach out to extended family and community members and involve them in parenting of children. This will expose the children to new thinking, experiences, shared values, and allow important social bonds to develop. Overall, a new parenting approach is necessary in view of the changed parenting environment and new culture.
\end{abstract}

Keywords: Contemporary Agĩkũyũ Society, Parenting, Parenting Environment.

\section{Introduction}

The environment in which an individual is brought up affects their well-being and development (Kaur, 2014). Studies show communal and family environments provide an amicable climate for a child's positive development (Knauer, Ozer, Dow \& Fernald, 2018) as different individuals bring their uniqueness to parenting. Such an environment not only supports parenting but also strengthens the 
parents' capacity to inculcate values into their children. Parenting is a societal issue. Billen (2015:35) agrees and asserts that parenting occurs within an interdependent environment and in the context of a community. Long (2004) supports this but goes ahead to talk about the various influences occurring in community, family and individual levels that impact on the way children are educated. The Agĩkũyũ community had a strong social system of participation and performance that supported parenting. According to McMillan and Chavis (1986) being part of the community made individuals feel valued and gave a sense of belonging. They perceived a shared faith that individual and group needs will be fulfilled owing to their resolve to be together. The Agĩkũyũ themselves, which Karũrĩ Parish community, our research area, is part of, were communal and relational. The communal relationships connected to the high levels of social cohesion that acted to reinforce healthy behaviours. Similarly, Conlon et al. (2015) argue that the home environment is an important setting in which children develop their healthy conduct.

The family is important because it establishes and preserves social norms, sanctions, and patterns of a child's conduct. It also directs the relationship between the child and parents and fosters mutual moral responsibility and support. Regrettably, a study by Shabas (2016) notes in recent times, social changes have destroyed traditional stereotypes of family bonds, and parenting practices. To destroy these parenting environments reduces the importance of the family relations as new cultures form. In this respect, some studies call for the creation of a suitable environment for young people to promote community values. However, they also show that it is not unusual today for young people who would otherwise benefit from the sense of community to be excluded from participation (Evans, 2007).

Ojukwu and Esimone (2014) explain that youth are getting exposed to vast environments associated with social changes which come with new cultures that contradict African moral values. Other studies by Zani (2013:53) and Gitonga, Mbũgua and Ogeda (2013:34) note the diminishing role of the community and extended family in parenting. Hill and Bush (2004) assert that there is a relationship between the parenting environment and children's behavioral problems. This study is motivated by this observation and therefore examines the parenting environment in a particular case of Karũri Catholic Parish in view of the impoverished youth behavior and subsequently moves on to make appropriate recommendations.

\section{Literature Review}

In an effort to expound the environment into which parenting takes place in the contemporary Agĩkũyũ society, this section will highlight relevant literature and will focus on the Agĩkũyũ family set up, parenting through rite of initiation, parenting in the home environment and community expectations.

\section{The Agĩkũyũ Family Set-up}

The Agĩkũyũ had a strong social system of participation especially on parenting of children. It was a good example of a stable outfit that relied on the strength of the kinship system (Kenyatta, 2015:1). Long (2004) explains the importance of such an environment by arguing that in it positive parenting occurs. He goes ahead to talk about the various changes at the community, family and individual levels that impact on the children education. According to Kenyatta (2015:67-105) and Billen (2015), parenting occurs within a certain environment with interdependent items and takes place against the background of many contradictions. 
INTERNATIONAL JOURNAL OF ACADEMIC RESEARCH IN BUSINESS AND SOCIAL SCIENCES Vol. 8, No. 8, August 2018, E-ISSN: 2222-6990 @ 2018 HRMARS

The Kinship system acted as a uniting factor (Kĩnoti, 2013:21). This system was the center of African life controlling social relationships in a given community, governed and regulated customs and influenced one's thinking and behavior towards another. Further, it influenced the whole life of individuals, and bonded together the entire life of the community (Mbiti, 1969:107). Cagnolo (2006:73) explains that the community and extended family had a role in parenting as a child belonged to the entire community while the kinship ties within the Agĩkũyũ society united every individual to a caring community and family.

Nyamiti (2010:9ff) shows that the family environment in which an individual grew up went beyond the physical realm. It consisted of both horizontal and vertical aspects of life comprising of the living, the dead or ancestors and those not yet born. Echoing the same idea, Mbiti (1969:107) enlightens that the living always have memories of the deceased while the departed watch over their living kin's affairs. The dead are the roots on which the living stand while the unborn children are the buds in the loins assuring the survival of the family. Leakey (1977:16-17) too is not left behind as he explains the Agĩkũyũ belief in ancestral and departed spirits was a fundamental basis of life. Thus the sense of communality was crucial for integral upbringing of children.

According to McMillan and Chavis (1986), everyone felt at home, valued and loved in the community. Individuals trusted their needs will be met. They feared being judged as selfish and were therefore not interested in acting alone (Healey \& Sybertz, 1996:68) but were eager to be invited to help which they freely did. In other words in this community dimension, mutual help was an asset for inculcating moral values into children. Mbiti (1969:106) explains this interdependence when he state that the individual exists because of the community, implying the community exists because of the individual. Similarly, it is unwise to overlook the role of family extensions when discussing the fundamental issue of parenting.

Bottignole (1984:31) asserts that the life of an African cannot be complete without the extended family. In the family, immense and rich knowledge is usually orally transmitted through family lines. We also learn all relatives are valuable in inculcating moral values in a child and enriching his or her spiritual life. For example, the Synod of African Bishops noted when grandparents are involved, they are the link between generations and play the role of ensuring family continuity and stability. By doing so they maintain the Psycho-affective balance necessary for transmission of customs and values (Synod of Bishops, 2016:21). This is why keeping the generational link is urgent.

Bottgnole (1984) laments that the all-embracing family and family life necessary for inculcating moral values is at risk as social changes occur in the Agĩkũyũ society. Wachege and Rũgendo (2017:691-711) discuss the increasing youth moral decadence and similarly note the present parenting environment is threatened by western culture just as Kenyatta foresaw years ago (Kenyatta, 2015:83-88). The result is a lessening role of the community and extended family in parenting. Other studies (Zani, 2013:53) and Gitonga, Mbũgua and Ogeda (2013:vii) also note this and associate the rising trend in adolescence immoral actions to poor parenting.

According to Zani (2013:53)'s study, "new features of the African family have emerged and merged with those that existed in the traditional setting." The adaptation has resulted in new parenting backgrounds. For instance the nuclear family has gained root in the modern African society and pays little regard to the extended family. Further, single parent families have emerged (Wachege, 2003:130-150). These families create a parenting environment where children grow up without the contribution of all parents especially fathers and also miss the essential contribution from extended family members. The extent of the single parent issue has recently received national attention. The Kenya National Bureau of Statistics (2014) puts the percentage of children living with their mothers 
INTERNATIONAL JOURNAL OF ACADEMIC RESEARCH IN BUSINESS AND SOCIAL SCIENCES

Vol. 8, No. 8, August 2018, E-ISSN: 2222-6990 @ 2018 HRMARS

only at $22 \%$ and is on the increase. Other changes in the community touch on the initiation rite discussed next.

\section{Parenting through Rite of Initiation}

The Agĩkũyũ culture socialized and taught children especially the youth in a corporate manner. This was done mainly through the initiation rite where they went through a systematic education process and prepared them for future life (Mũgambi, 2009:196-197). This made initiates develop a special bond between them and they considered themselves as family (Kĩnoti, 2013:21). The group initiation ensured members belonged to one another as age-mates. They were collectively responsible for keeping and maintaining the good name of the group since each age-group was keen to keep honour and good reputation.

Personal integrity was important not only for the sake of one's reputation but also for age-group members and families. Any conduct of an age-mate that did not meet the approval of others or did not meet the standard was met with corrective measures (Kĩnoti, 2013:22). This rite was thus vital in dictating the behaviour and status of every individual and by extension created harmony in community activities. Unfortunately, as society changes, group informal teaching significantly loses its value. Today, the initiation rite has drifted more towards an individual affair (Gachũhi, 2017) restricted within the immediate family environment.

\section{Parenting in the Home Environment}

The child is born into-the human family and progressively through education into the human community where he or she is supposed to mature and start giving back. In the Agĩkũyũ community, children spent most of their early years within the home environment. They learned language and behavior without suppression of their developmental processes (Diamond, 2013) and the presence and involvement of both parents at home raising their children in a complimentary manner was important. The father's presence confirmed legitimacy and brought confidence in the children's lives. A child who perceives legitimacy and therefore complete may develop the confidence needed to face life and find it easy to make success out of their situation (Lasse, Fite \& Wadende, 2011).

In the Agĩũyũ home, the parents endeavored to cultivate the right values in their children by ensuring the boy and girl shared in their parents' lives. According to Kenyatta, the sharing in life together and doing simple duties in imitation of the parents, and alongside the great interest of parents towards the children was largely responsible for creating strong bonds among the family members (Kenyatta, 2015:69). These bonds acted as pillars for the success of the family and the foundation for children acquiring life skills. In particular a strong bond was sustained by the presence of the father and his commitment to the family. Wachege and Rũgendo (2017) found out that where any of the parents is lacking "the children concerned miss the contribution of the lacking parent and are bound to compare their situation with their peers who have both parents".

Lasse et al. (2011) examine the father's role and note that historical and cultural factors dictate parenting duties. Cagnolo (2006:51) explains that even though the father's leadership at home created an authoritative atmosphere, he was a loving affectionate figure. In the evenings, as the family sat around the traditional fire while dinner cooked, he held a child between his knees still having a merry conversation with his wife. This loving gesture is further demonstrated when Leakey (1977) notes "although from every animal that was slaughtered (in ordinary family feast or meal) 
INTERNATIONAL JOURNAL OF ACADEMIC RESEARCH IN BUSINESS AND SOCIAL SCIENCES

Vol. 8, No. 8, August 2018, E-ISSN: 2222-6990 @ 2018 HRMARS

certain joints belonged to the children, others belonged to the women, and yet others to the men, it was seldom that a father did not give bits of his own portion to his children and to his wife." He ensured that everyone was well fed. Growing up in such an environment imparted in the children the important values of love, sharing, care, respect and humility which are community values.

\section{Community Expectations}

In many traditional environments, the community placed expectations on what the child should do and say (Norwegian Ministry of Children, 2014). The society also prescribed the nature of socialization the child received (Eliot, 2010). A study by Chang'ach (2012:181-188) supports this by illuminating that in Kenya, traditional customs and beliefs determine the behaviour of children and what activities they engage in. Thus, the Agĩũyũ traditional education emphasized on a particular act of behaviour in a concrete situation. Most education was imparted within the sphere of personal relationships facilitated by a definite and practical structure (Kenyatta, 2015:60).

Community values were taught to the individual and the parenting effort was aimed to farther the goals of the community. The individual acted according to the wishes of the community. The individual goals were subordinate to those of the community (Katola, 2014:31-39) and the many community rules acted as a deterrent and in a way made parenting easier. Aided by these rules, systematic effort was made to train the boy and girl on character, social responsibility and behaviour. If any child misbehaved, Cagnolo (2006:74) explains, he or she was disciplined by any mature person who happened to be conveniently near since a child was considered as belonging to the community. However today, the values and goals inculcated into children differ considerably within a community and across communities. This is because today's parenting is carried out according to what the individual parents deem acceptable and appropriate (Bornstein et al. 2017) which may ignore societal norms.

\section{Research Methodology}

Three complementary theories guided this study: Erikson's (1998:32ff) psychosocial theory; Boff and Boff's (1987:24-39) mediation theory and social learning theory by Bandura (1977). The psychosocial and mediation theories provided methodological support while the social learning theory gave insight on parenting environment. In the case study survey 115 respondents took part. Both primary and secondary data was collected and analyzed thematically to address the research objectives. The distribution of questionnaires ensured parents with children at various stages were considered. Similarly, the distribution considered youth at various stages of growth. Interviews targeted individuals considered to have specific needed information. The validity and reliability of the questionnaire instrument was maintained by ensuring that it had same questions for each group of respondents, reviewed by colleagues and piloted before being put into use.

\section{Findings}

\section{Agĩkũyũ Family Set Up}

Prior literature has shown that the Agĩkũyũ social setup was fundamental in bringing up an individual. The respondents lamented that some social arrangements for bringing up children no longer exist in their original form or are functioning minimally. As a result they do not play a major role in the life of an individual. This finding parallels Wachege (1992:14)'s outcome that Agĩkũyũ social organization in which an individual grew has substantially remained the same even though functionally changed. For instance, it is rare to witness the work of the mbarĩ (sub-clan). Besides, government organs presently 
perform the work of the mbarĩ council. Other functions of structures such as nyũmba (family group or extended family) and mũhĩrĩga (clan) have also changed. This too has affected uniting and bonding characteristics of the community such as common lineage and origin, same religion, same basic social life and morality. Living away from the same neighbourhood of related relatives further complicates the situation as people cannot intermingle easily.

Further, over time, the important boys' initiation rite, whose main purpose was to educate the youth as a group on life issues necessary to be responsible people in the community has undergone changes too. According to the elder respondents, group initiation was important because of its educational purpose. The practice provided the right atmosphere for affirming positive values for the benefit of the individual and a whole generation. The study revealed Karũrĩ community stopped practicing traditional group initiation a while back and therefore the associated age-group concept has lost meaning (Elders, 2016). These include social control and maintaining of healthy interpersonal relationships even in difficult times. The elder's report the age-group was last active in its original sense several years ago. They claim the declining morality among the youth is a result of abandoning the group initiation rite and its associated age-group practice. Besides, the initiation rite today, except the Catholic Men Association (CMA) version, is more of a ritual than a well thought technique for inculcating values into young men.

Another general opinion in the area is since young people are no longer initiated together, they lack the uniting characteristic. They therefore do not feel obliged to correct the wrongs of their peers. For instance, unity is lacking among them as far as the resolve to remain moral is concerned. In the past, age mates would be concerned if any group member misbehaved. They ensured the mistake was not repeated. In recent times, the Agĩkũyũ Council of Elders has revitalized the rite and some of its functions for not only teaching moral values and life skills to male youth but also for recovering some aspects of Agĩkũyũ culture. In one way, the rite is sponsored by the CMA.

The study found the contemporary Karũrĩ Parish community, just like in the old days, has expectations of what a child should do or should not do (Lasse et al., 2011; Eliot, 2010). However, the community does not have mechanisms to ensure the nature of socialization the child receives is as prescribed. The lack of elaborate arrangements for educating children in Karũrĩ impacts on teaching of values. Further, a loss of generational information has occurred since their cultural institutions acted as custodians. Today, the information can only be provided by a few elders willing to volunteer any information.

Not unsurprising, the youth score the school most in providing a fairy reasonable environment for learning in many ways. They also pointed out the Church as responsible for their religious training and offering some entertainment opportunities. However, the youth is facing hard times and choices, and they still have few effective avenues to express their concerns and be understood. They are disillusioned with family and religious institutions and they see them as more often than not unwilling or unable to deal with particular youth issues. Consistent with the youth's thought is disturbing truth the sense of community is fast diminishing.

\section{Sense of Communal Life}

Today, the sense of community in Karũrĩ is far from what Kenyatta (2015) and Zani (2013) refer to as a place where everyone educates a child. In this community, the individual's life and parenting of children is largely one's affair (Mbũgua, 2014:40) which is fiercely opposed to the African community life ideal. Help extended by the community and extended family cushions children from myriad social 
issues such as marital problems, and, family poverty and unemployment (National Authority for the Campaign Against Drug Abuse, 2014). According to Mbiti (1969:108-109), the community "created the individual" while the African communal life provided a corporate environment in which the individual existed. The individual therefore was expected, to quote Areji et al. (2015), “...to live...in a community." Thus the communal participation in bringing up a child conveys the African worldview that accentuates the values of family relationships, parental care, sharing, self-sacrificing, hospitality and concern for others.

However, despite the observation above, the sense of community is still viewed as offering the best parenting environment. Today, people encounter display of this Agĩũyũ sense of community though at a lower scale than in traditional society. The study found few respondents bother to give word of advice or offer impromptu correction to neighbour's children. Moila (2002) argues that the disruption of this sense of communality should call for an intervention as it negatively impacts on parenting. The paragraphs above show Karũrĩ community is clearly conscious of the benefits of communal life on which its prosperity partly depends. This consciousness was a driving force in the traditional Agĩũyũ community which had a saying "wealth comes by working together." This saying was always in the minds of the people as it reminded them of their inter-dependency as a common people. To prosper, it was essential to work hard in a supportive genuine atmosphere of cooperation between the family, clan and community (Gathogo, 2008) even in teaching the children as they grew up. The response from the respondents show everyone from parents to neighbours, Church and other community members believe everyone has a part to play in inculcating moral values into young people, though this is not the case today.

\section{Involvement of Neighbours}

The Karũrĩ elders and parents lament there are few good neighbours today who can be trusted with the watchman role over children. One respondent wondered "...before it was there...people do not receive it well these days..." Further, most neighbours do not often volunteer communal acts like guiding or disciplining neighbours' children. For instance, when an adult comes across a child doing wrong, the first thought is not of how to correct him or her but of how the parent will react. This is because some parents will not receive it positively. What makes neighbours shy away from indulging in another's affair without invitation is partly the individualistic tendency of individuals today.

As articulated before, the social fabric in the traditional society anchored on people's concern for others' wellbeing. The parenting effort in Karũrĩ Parish community is no longer a communal affair though few instances where a neighbour disciplines another's child still happen, albeit rare. This finding is in line with Bornstein et al. (2017)'s assertion that today's parenting depends on what individual parents consider acceptable and suitable for their children. In effect, however, such parenting results in children being denied the much-needed association and learning in an un-caring neighbourhood. Thus the children still need attention and moral education by all especially in light of the African understanding that children are blessings from God for the whole community. However, it is at home where the child first learns social values.

\section{Home Environment}

The parent respondents agree with the assertion that the family environment is the first place where children should learn moral values. When asked what they regard as family, majority of the respondents pointed out the family comprises of the father, mother and children; that is the nuclear 
family. The extreme is where respondents described the father figure as family. They probably thought of the mbarĩ where the father's lineage name was the family. A few respondents consider inclusion of grandparents, aunts and uncles as part of the family. Their inclusion makes the family an extended one. Some respondents recognize the extended family as important in socializing children although this role is now reduced and sometimes non-existent. For correct rooting without partiality, the aunt and uncle provided guidance for the boy and girl respectively.

Moreover, most parent respondents view the extended family members as having an advantage over them in some areas. This is clear when most qualify the grandparents, aunties and uncles as individuals with much to contribute especially to social, physical, psychological and moral development of the child. Further, the youth can afford to be open and hold free discussions with them. Zani (2013:53) says "...exposing children to a large network of aunts, uncles and grandparents with whom children could share intimate queries without feeling uncomfortable or shy" can be beneficial to children. Still, grandparents and other family members older than the parents have more experience in life issues and can guide and share experiences on many topics (Bastien, Kajula \& Muhwezi, 2011).

On their part, the youth respondents feel the relatives are kind, understanding, inspiring and encouraging. Besides, the grandmother entertains them with stories. This soft side of the relatives may provide an aura that is favourable for inculcating moral values in the children as they elicit good feelings in them. The youth view them as more positive towards life than immediate family where life is seen as mechanical, always serious with the parents issuing demands and controlling deliberations. Unfortunately, as Strobbe, Olivetti and Jacobson (2011) assert, broken intergenerational ties will have a marked effect on parenting in Karũrĩ as interactions reduce. This is what children will miss as they grow up. The relatives should contribute more now when many parents are in formal employment or other business and therefore busy.

The findings agree with Zani (2013:52) who states that the need to help one another should prompt individuals to reach out to other family members. This would resonate with the African proverb "it takes a village to bring up a child," meaning, bringing up a child is a corporate effort where everyone in the family takes part. This brings up the issue of single parent families, a phenomenon which is easily noticeable in Karũrĩ Parish where quite a number of the respondents were single parents. This is unlike in the traditional Agĩkũyũ society where steps were taken to ensure children grew in an environment comprising of a father and mother; the society then did not think well of a single mother (Ishii, 1997). The kind of home environment where parenting occurs affects parent-child relationship which is discussed next.

\section{Parent-Child Relationship}

The study found that the parent-child relationship in Karũrĩ affects the quality of parenting a child receives. The children's disobedience, parent's behaviour and desertion of parenting duties all affect the relationship. This collaborates O'Connor and Scott (2007:21-22)'s finding that a poor parent-child relationship results in negative outcomes such as aggressive behaviour. On the other hand, the unique abilities of children, their temperaments and predispositions play a central role in forming and maintaining quality parent-child relationships (Gross, Shaw, Moilanen, Dishion \& Wilson, 2008). This study found this observation to be true in Karũrĩ.

The parent's presence and involvement at home affects the parent-child relationship. Besides, Karũrĩ parents show a degree of ignorance, negligence and lack of skill in parenting which complicates the relationship. By observation, the researchers noticed many young children kept themselves busy by 
playing with toys without the mother's active participation in directing them learn something useful through play. On the other hand, the father's disciplining authority, as a parenting background, is diluted. The strong and passionate authoritarian father-figure in the Agĩũ̃y family ensured discipline within the family and his word was obeyed without questioning. Today most fathers have become models of imitation by their children for wrong actions like substance abuse. The father's status today in several cases is un-inspiring. Further, his absence from home lessens his compassionate participation in his children's lives including taking part in activities such as play and sharing of meals. This robs the children of the father's love which is the basis of their emotional development. It is not surprising then the study found most children learn without supervision of parents which impedes development of autonomy in them.

The parents in Karũrĩ Parish know a poor parent-child relationship constrains inculcating of moral values. This study found out even though most parents felt a positive relationship existed between them and their children, most youth were more comfortable dealing with their mother. However, a lower percentage was comfortable dealing with both parents. Through parenting seminars Karũrĩ parents are starting to know when the relationship between parents and children is sincere and open, the child may be encouraged to turn to the parents first whenever need arises. However, they are aware this may not be a straight forward reaction from the youth given the new cultural environment.

\section{New Cultures}

This study shows new cultures have emerged and are having a marked effect on Karũrĩ Parish youth and the way moral values are inculcated into them. By their own admission and deeds, the informants appear substantially influenced by new forces in the community. The Agĩũ̃ỹ culture like any other is not static and therefore is not purely traditional today. In line with what George (2003) noted in his study, the new culture has brought with it contradictions between traditional and modern lifestyles in Karũrĩ Parish community. In this culture, perceptions and meanings of social values are reprogrammed usually taking a contradictory stand to that of parents and society. The older members of the community regard the new culture as a break-away from tradition. For instance there is an apprehension among parents about use of social media by youth. One reason for this is its ability to significantly contribute to the formation of new culture as youth interconnect easily and quickly. Sivi (2011:59) elaborates this as connected to the thought that introducing doubt in established and accepted values and norms as the internet does will give access for young people to accept alternative choices and lifestyles. Just like their sons and daughters, some parents too are much engrossed in western culture to the extent they forget their very own Agĩkũyũ culture that safeguards morals.

The youth's behaviour and life style is a culture change that has already occurred (Kange'the 1981:43). In this new culture, the battle of winning children and youth back to listen to their parents is a tough one considering the nature of our modern economy, which many studies note, contributes most to the situation the society finds itself in. McGarry and Ryan (2001:30) admit the difficulty in parenting today and adds; a story can only be relevant when it communicates in the people's language.

\section{Conclusion and Recommendations}

The study has examined the parenting environment in Karũrĩ Parish and in particular dealt with the sense of community, extended family, initiation rite, parent-child relationship and new cultures. The several almost irreversible changes in the community and the changed parenting environment ensure 
parenting is not receiving a boost from resourceful people like the grandparents, uncles and unties. However, the success of the parenting effort depends on the environment the parents and community create. The question is; are the parents and community willing to commit and make the environment suitable for holistic parenting? Although much has changed, the parents and community of Karũrĩ can mobilize the power they have and create an atmosphere suitable for parenting different from the current one. Inevitably, this demands huge individual sacrifices and adjustment to their lives.

The following are recommendations arising from the findings:

i. The parents should understand that proper rooting of children is important for their development and their duty therefore is to find an amiable environment for children to grow and learn in. Going by the findings, today's children in Karũrĩ Parish need much parental support. Instead of lamenting, the elders and parents should ask themselves what went wrong and start taking action. They are the community.

ii. The decreasing role of the community and extended family calls for parents to rethink the parenting environment especially now when they are busy people. The community can offer a lot especially where the parents are away or busy. To involve the community in parenting will benefit the children through exposure to different thinking and socialization.

iii. Where applicable, social mechanisms should be put in place for children's socialization, uniting, bonding and learning on same basic social life skills and morality. The community should support the CMA's effort to have boys taught together. Viewing the initiation rite as a well thought technique for inculcating values rather than as a mere ritual is the way to go. More sensitization should be made to the wider community to create opportunities for children to take part in and receive positive teaching.

iv. Often, parents should introduce their children to the extended family members on both sides. Further, family get-togethers should be encouraged because they create a suitable environment for interacting and telling stories loaded with rich Agĩunyũ wisdom, religious beliefs, ideals, morals and warnings. This is to say that parents can still revisit whatever is good for teaching moral values. Going back to what has been abandoned is not forbidden.

v. It is suitable for children to be brought up in an environment where both the father and mother contribute in their upbringing. Both should create opportunities and spend time with their children especially from early age. Therefore, the father should heed the call made by youth respondents to be in the forefront in teaching them life skills and providing emotional support.

vi. The parents are partly to blame for deserting their children. They must understand children need active parent supervision and direction. The father's actions should be gratifying. They should not allow children to imitate them for the wrong reasons.

vii. Where parenting is under a single parent, the parent should allow close family members or trusted friends of the opposite gender such as an uncle or aunt to take part in bringing up the child. Their involvement will benefit the children emotionally, give them confidence in the eyes of their peers which will give then a social balance.

viii. As new culture take root in Karũrĩ community offering a challenging environment for parenting, parents and the community ought to understand this culture has arrived and may demand ingenious ways of holistic parenting. Similarly, the parents and community should know Agĩkũyũ culture like any other is dynamic and cannot be as purely traditional today. The solution now lies in finding the best way for enabling the parenting effort succeed in such an environment. 
INTERNATIONAL JOURNAL OF ACADEMIC RESEARCH IN BUSINESS AND SOCIAL SCIENCES

Vol. 8, No. 8, August 2018, E-ISSN: 2222-6990 @ 2018 HRMARS

\section{Areas for Further Research}

Although this study explored the parenting environment in a single community, the issue affects many other communities in Kenya. Therefore, similar studies could focus on other communities in the subject matter to draw a general conclusion of this important issue. Other studies could focus on understanding the environment in which some children receive day care in organizations where their mothers work.

\section{Corresponding Author}

Florida G. Rũgendo

Department of Philosophy and Religious Studies

University of Nairobi, Email: fkamakia@gmail.com

\section{References}

Areji, A. C., \& Anyaehie, M. C. (2015). Igbo traditional morality as a panacea to Nigerian security crises. Open Journal of Political Science, 5, 102-108.

Bastien, S., Kajula, L. J., \& Muhwezi, W. W. (2011). A review of studies of parent-child communication about sexuality and HIV/AIDS in Sub-Saharan Africa. Reproductive Health, 8(25). https://www.ncbi.nlm.nih.gov/pmc/ articles/PMC3192730/

Billen, R. M. (2015). Interdependent determinants of parental involvement among families of children receiving early intervention services. http://trace.tennessee.edu/utk_graddiss/ 3396

Boff, L., \& Boff, C. (1987). Introducing liberation theology. MaryKnoll, New York: Orbis Books.

Bornstein, M. H., Putnick, D. L., Oburu, P., Lansford, J. E., Deater-Deckard, K., Bradley, R. H., ..., \& Britto, P. R. (2017). Parenting, environment, and early child development in Sub-Saharan Africa in Abubakar, A., \& Vijver, F. J. R. (2017). Handbook of applied developmental science in Sub-Saharan Africa. New York: Springer.

Bottignole, S. (1984). Kikũyũ traditional culture and Christianity. Nairobi: Heinemann Educational Books.

Cagnolo, C. (2006). The Agĩkũyũ: Their customs, traditions and folklore (New Ed.). Nairobi: Wisdom Graphics Publication.

Chang'ach, J. K. (2012). An unfinished agenda: Why is the boy child endangered? International Journal of Academic Research in Business and Social Sciences, 2(4), 181-188.

Conlon, B. A., McGinn, A. P., Lounsbury, D. W., Diamantis, P. M., AGroisman-Perelstein, A. E., WylieRosett, J., \& Isasi, C. (2015). The role of parenting practices in the home environment among underserved youth. Childhood Obesity, 11(4), 394-405.

Diamond, A. (2013). Executive functions. Annual Review of Psychology, 64, 135-168.

Eliot, L. (2010). The truth about boys and girls. https://www.researchgate.net/ publication/ 42836385_The_Truth_about_Boys_and_Girls

Evans, S. D. (2007). Youth sense of community: Voice and power in community contexts. Journal of Community Psychology, 35(6), 693-709.

Gachũhi, K. (2017). Modern revolution on traditional circumcision practices. https://www. standardmedia.co.ke/article/2001263371/Church-leaders-push-traditions-far-away-fromcircumcision

Gathogo, J. M. (2008). Some expressions of African hospitality today. Scriptura, 99, 275-287. 
INTERNATIONAL JOURNAL OF ACADEMIC RESEARCH IN BUSINESS AND SOCIAL SCIENCES

Vol. 8, No. 8, August 2018, E-ISSN: 2222-6990 @ 2018 HRMARS

George, S. (2003). Emerging youth cultures in the era of globalization: Techno culture and terror culture in Tiplady, R., One world or many?: The impact of globalisation on mission. Pasadena: William Carey Library.

Gitonga, J., Mbũgua, S. W. N., \& Ogeda, J. (2013). Skilful parenting and molding behaviour at an early age. Nairobi: Parenting in Africa Network.

Gross, H. E., Shaw, D. S., Moilanen, K. L., Dishion T. J., \& Wilson, M. N. (2008). Reciprocal models of child behavior and depressive symptoms in mothers and fathers in a sample of children at risk for early conduct problems. Journal of Family Psychology, 22(5), 742-751.

Healey, J. G., \& Sybertz, D. (1996). Towards an African narrative theology. Nairobi: Paulines Publications Africa.

Hill, N. E., \& Bush, K. R. (2004). Relationships between parenting environment and children's mental health among African American and European American mothers and children. Journal of Marriage and Family, 63(4), 954-966.

Ishii, Y. (1997). Birth control and reproduction in the Kikuyu society: The case from Murang'a District in Kenya. African Study Monographs, 18(3 \& 4), 191-201.

Kang' ethe, K. (1981). The role of the Agĩkũyũ religion and culture in the development of the Karing'a religio-political movement, 1900-1950 with particular reference to the Agĩkũyũ concept of God and the rite of initiation (Unpublished PhD Thesis). Nairobi: University of Nairobi, Kenya.

Katola, M. T. (2014). Incorporation of traditional African cultural values in the formal education system for development, peace building and good governance. European Journal of Research in Social Sciences, 2(3), 31-39.

Kaur, J. (2014). Adolescents' perception of parenting as related to family environment in defence officers families in India. International Journal of Scientific \& Engineering Research, 5(2), 93110.

The Kenya National Bureau of Statistics. (2014). Economic survey. https://www.knbs.or.ke/ download/economic-survey-2014/

Kenyatta, J. (2015). Facing Mount Kenya. Nairobi: East Africa Publishers.

Kĩnoti, H. W. (2013). Africa ethics: Gĩkũyũ traditional morally. Nairobi: CUEA Press.

Knauer, H. A., Ozer, E. J., Dow, W., \& Fernald, L. C. H. (2018). Stimulating parenting practices in indigenous and non-indigenous Mexican communities. International Journal of Environmental Research and Public Health, 15(29), 1-16.

Lasse, J., Fite, K., \& Wadende, A. P. (2011). Fatherhood in Kenyan ethnic communities: Implication for child development. School Psychology International 32(1), 49-57.

Leakey, L. S. B. (1977). The Southern Kikuyu before 1903 Volume I. New York: Academic Press.

Long, N. (2004). The changing nature of parenting in America. Pediatric Dentistry, 26(2), 121-124.

Mbiti, J. S. (1969). African religions and philosophy. Washington: Praeger Publishers.

Mbũgua, J. N. (2014). Study to formulate a model for Agĩkũyũ Christian funeral rites that would integrate relevant cultural, scriptural and practical norms. Bryanston: South African Theological Seminary.

MCgrarry, C., \& Ryan, P. (2001). Inculturating the Church in Africa: Theological and practical perspective. Nairobi: Paulines Publications Africa.

McMillan, D. W., \& Chavis, D. M. (1986). Sense of community: A definition and theory. Journal of Community Psychology, 14, 6-23.

Moila, M. P. (2002). Challenging issues in African Christianity. Pretoria: CB Powell Bible Centre.

Mũgambi, J. N. K. (2009). Christianity and African culture. Nairobi: Acton Publishers. 
INTERNATIONAL JOURNAL OF ACADEMIC RESEARCH IN BUSINESS AND SOCIAL SCIENCES

Vol. 8, No. 8, August 2018, E-ISSN: 2222-6990 @ 2018 HRMARS

Norwegian Ministry of Children, Equality and Social Inclusion. (2014). Equality: The Norwegian Government's gender equality action plan. https://www.regjeringen.no/ globalassets/upload/bld/action_plan_2014.pdf

Nyamiti, C. (2010). Studies in African Christian theology Volume 1: Jesus Christ, the Ancestor of humankind: Methodological and trinitarian foundation. Nairobi: CUEA Press.

O'Connor, T., \& Scott, S. (2007). Parenting and outcomes for children. New York: Joseph Rowntree Foundation.

Ojukwu, E. V., \& Esimone, C. C. (2014). Inculcating morals in adolescents through the Igbo folk music. Presented at the WEI International Academic Conference, New Orleans, USA. https://www.westeastinstitute.com/wp-content/uploads/2014/11/ Ojukwu-and-simone.pdf

Shabas, S. (2016). Relationships between parents and preschool-age children attending kindergartens. Procedia - Social and Behavioral Sciences, 233, 269-273.

Sivi, K. (2011). Kenya youth scenarios: Youth.... the key to unlocking Kenya's potential. Nairobi: Institute of Economic Affairs.

Strobbe, F., Olivetti, C., \& Jacobson, M. (2011). Breaking the net: Family structure and street children in Zambia. file:///C:/Users/User/Downloads/Breaking_the_Net_Family_ Structure_and_Street_Child.pdf

Synod of Bishops. (2016). The vocational and mission of the family in the Church and in the contemporary world. Nairobi: Paulines Publications Africa.

Wachege, P. N. (1992). Jesus Christ our mũthamaki (ideal elder): An African Christological study based on the Agĩkũyũ understanding of elder. Nairobi: Phoenix Publishers.

Wachege, P. N. (2003). Third millennium African single mothers and mother widows: Ethno-religiophilosophical touch. Nairobi: Signal Press.

Wachege, P. N., \& Rũgendo, F. G. (2017). Effects of modernization on youths' morality: A case of Karũri Catholic Parish, Kenya. International Journal of Academic Research in Business and Social Sciences, 7(12), 691-711.

Zani, P. (1999). The family in its African socio-context, in Ryan, P. (Ed.), The models of "Church-asFamily": Meeting the African challenge. Nairobi: CUEA Press. 